\title{
Observaciones introductorias de la homilética agustiniana para la predicación actual
}

\section{Introductory remarks of the Agustinian homiletic to current preaching}

\author{
José María Siciliani Barraza
}

\section{Resumen}

El artículo aborda en primer lugar la experiencia de San Agustín como oyente de sermones y sitúa el tema de la homilética en el campo de la teología práctica. En segundo lugar, recoge algunas ideas fundamentales sobre la retórica al servicio de la predicación cristiana según san Agustín. En tercer lugar, señala la crisis de la predicación actual para concluir con la formulación de tres desafíos que el pensamiento homilético de san Agustín lanza a la homilía actual. Estos tres desafíos se articulan justamente con las tres finalidades de la predicación cristiana según san Agustín: enseñar, deleitar y conmover. Bien articulados, estos tres objetivos, podrían evitar los riesgos actuales de irracionalismo, de emocionalismo y de practicismo en la homilía.

Palabras claves: Homilía, retórica, san Agustín, homilética, teología práctica.

\footnotetext{
${ }^{1}$ Este artículo sale de las investigaciones en teología narrativa práctica que el autor adelanta en la Universidad De La Salle de Bogotá. En Particular del proyecto "Una lectura de los personajes bíblicos en la catequesis: aportes para la reconstrucción y la paz”, con código FCE.CV-012013-01, financiado por la Facultad de Ciencias de la Educación de la Universidad De La Salle de Bogotá.
} 


\begin{abstract}
Firstly the article approaches the experience of St. Augustine as a listener of sermons and places the subject of homiletics in the field of practical theology. Secondly, it collects some fundamental ideas about rhetoric at the service of Christian preaching according to St. Augustine. Thirdly, it points to the current crisis of preaching to conclude with the formulation of three challenges that the homiletic thought of St. Augustine release to today homily. These three challenges are articulated precisely with the three purposes of Christian preaching according to St. Augustine: teaching, delighting and inspiring. Well-articulated, these three objectives could avoid the current risks of irrationalism, emotionalism and practicality in homily.
\end{abstract}

Keywords: Homily, Christian rhetoric, saint Agustine, homiletic, practical theology.

\title{
Introducción
}

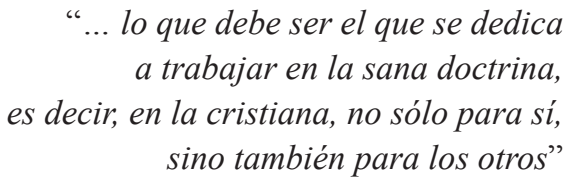

(San Agustín²).

La evangelización, tarea esencial de la Iglesia, se hace hoy en contextos sociales y culturales radicalmente diferentes: un sociedad tecno-científica, agobiada por una crisis ecológica profunda, con un estilo de vida agitado por el frenesí y la eficacia, la pérdida de los vínculos sociales y la secularización creciente, que va de la par con un ateísmo práctico, sobre todo en varios países latinoamericanos cuyos habitantes, en su gran mayoría, se confiesan creyentes. Todos esos factores afectan a la misión evangelizadora de la comunidad eclesial y, por consiguiente, a la homilía. ¿Qué puede entonces aportar la experiencia de un predicador de la talla de san Agustín? ¿Qué exigencias formulan, a quienes tienen la responsabilidad de hacer la homilía, los postulados de san Agustín sobre la predicación?

\footnotetext{
${ }^{2}$ San Agustín, De Doctrina Christiana, Madrid, BAC, 1957, Libro IV, capítulo XXXI, 64. De ahora en adelante este texto será citado con la abreviación DC.
} 
El orden de exposición de este trabajo pretende ofrecer algunos elementos de repuesta a estas preguntas. Con tal fin, se tratarán tres puntos esenciales así: en primer lugar, se evocará la experiencia misma de San Agustín como auditor de sermones. Se mostrará qué es lo que puede realmente impactar o tocar el corazón de los auditores de una homilía o de un sermón, según el estilo de predicación presente en los sermones de san Agustín. Como parte de este primer punto, se esbozará el horizonte teológico-práctico, base de este trabajo, definido como fides quaerens Verbum efficax ${ }^{3}$. En segundo lugar, se observarán algunas ideas fundamentales del libro cuarto De Doctrina christiana, dedicado al arte de predicar, insistiendo en el estilo homilético propuesto por San Agustín. En tercer lugar, para finalizar, y con base en los planteamientos de los apartados uno y dos, se mostrarán los desafíos que tales planteamientos lanzan a la predicación cristiana actual y los aportes que la retórica subyacente en los sermones de san Agustín puede hacer a la homilía actual.

\section{San Agustín como oyente de sermones}

\subsection{Su experiencia con el maniqueo Fausto}

En un momento de su vida en que está buscando ansiosamente la verdad, y que escucha a los Maniqueos, San Agustín se siente defraudado por los discursos de muchos miembros de este grupo, que no le enseñan nada nuevo o que son incapaces de responder satisfactoriamente sus preguntas. En ese contexto, cuando estaba entre los 20-30 años, escribe san Agustín: "Durante esos nueve años bien corridos en que con inmenso deseo de verdad pero con ánimo vagabundo escuché a los maniqueos, estuve esperando la llegada de dicho Fausto"4. Cabe anotar enseguida qué clase de auditor es Agustín: un oyente perspicaz que interroga a los predicadores; un oyente que busca la verdad, ansiosa pero críticamente. Y Agustín recuerda su encuentro con Fausto en estos términos breves: "Cuando Fausto por fin llegó me encontré con un

\footnotetext{
${ }^{3} \mathrm{Al}$ escribir estas líneas sobre la teología práctica nos inspiraremos en el texto siguiente de Marcel Viau, "De la théologie pastorale à la théologie pratique", en Gilles Routhier - Marcel Viau (Dir.), Précis de théologie pratique, París - Bruselas - Montreal, ediciones L'Atélier Lumen Vitae - Novalis, 2007'12, p. 41-53. A la expresión Fides quaerens intellectum, nosotros añadimos adrede el adjetivo efficax en latín.

${ }^{4}$ San Agustín, Confessiones, Madrid, BAC, 1986, libro 5, VI, 1. De ahora en adelante este texto será citado con la abreviación Conf., y se indicará seguidamente el libro, el capítulo y el numeral, siguiendo la subdivisión del texto.
} 
hombre agradable y de fácil palabra"s. E inmediatamente resume su reacción o el impacto que los discursos del famoso maniqueo le causaron: "Pero decía lo que todos los demás, sólo que con mayor elegancia"6.

Merece resaltarse esta observación final de Agustín sobre la facundia de Fausto, porque no es justamente dicha locuacidad lo que lo deslumbra, sino que, por el contrario, lo deja defraudado. Agustín lo dice con una expresión fuerte: "De las cosas que decía estaban ya hartos mis oídos y no me parecían mejores porque él las dijera mejor, ni verdaderas por ser dichas con elocuencia; ni sabia su alma porque fuera su rostro muy expresivo y muy elegante su discurso" ". Las cosas que decía Fausto ya las conocía Agustín, y no era eso lo que ansiaba su alma, no era lo que podía saciar su sed, metáfora con la que él describe su búsqueda. Y aquí san Agustín critica a todos aquellos que le habían ponderado a Fausto. En realidad el único criterio que tenían para acreditarlo era la elegancia de su discurso. Pero, como se constata, eso no es lo que convence al futuro obispo de Hipona. La argumentación fundamental de Agustín sobre el punto está formulada en estos términos: "Mas para esta época ya había aprendido de ti, Señor, por modos ocultos y maravillosos $-\mathrm{y}$ creo que eras tú el que me enseñabas, porque era verdadero aquello, y nadie puede ser maestro de la verdad sino tú, sea cualquiera el lugar y modo en que ella brille-, ya había aprendido de ti que no por decirse una cosa con elegancia debía tenerse por verdadera, ni falsa porque se diga con desaliño; ni a su vez verdadero lo que se dice toscamente, ni falso lo que se dice con estilo brillante; sino que la sabiduría y necedad son como manjares, provechosos o nocivos, y las palabras elegantes o triviales, como platos preciosos o humildes, en los que se pueden servir ambos manjares"8.

Aunque el oyente quisiera sentir afirmaciones en torno a la subordinación de la forma sobre la prioridad del contenido, él se sorprende al percibir que san Agustín apreció y disfrutó de la elegancia oratoria de Fausto. Agustín, de facto, desmiente tal expectativa cuando recuerda incluso el deleite experimentado: "La avidez con que había yo por tan largo tiempo esperado la llegada de aquel hombre me hacía ciertamente deleitarme en la vivacidad y animación con que disputaba, y en el feliz tino con que hallaba las palabras justas, que fácilmente

\footnotetext{
${ }^{5}$ Ídem.

${ }^{6}$ Ídem.

7 Ídem.

${ }^{8}$ Conf. Libro 5, VI, 10.
} 
le venían para revestir sus sentencias" ". Lo único que molestaba a Agustín era que no le dejaran dialogar con el orador, que no le permitieran un encuentro más familiar en que él pudiera proponerle sus dificultades. San Agustín no se deja deslumbrar por la rutilancia de las palabras. Las preguntas hondas que tiene son graves y no bastan palabras bien organizadas y cuidadosamente escogidas para resolverlas. Agustín quiere un diálogo personal, un encuentro cercano que le permita decir sus dudas profundas al orador y discutir con él. No es pues la elocuencia lo que toca su corazón, a pesar de que su sensibilidad sea deleitada.

Y cuando Agustín tiene la oportunidad de encontrarse con Fausto en un círculo más cerrado y amistoso, le expone sus dudas. Constata entonces la ignorancia de Fausto con respecto a las disciplinas liberales (exceptuando la gramática), que incluso conocía rudimentariamente ${ }^{10}$ : "Cuando aquel hombre, a quien había yo tenido por excelente conocedor de las artes liberales se me apareció en toda su impericia, comencé a desesperar de que pudiera él aclarar mis problemas y resolver mis dudas"11. San Agustín afirma textualmente que su ilusión quedó rota al contacto con Fausto, y que incluso cierta desesperación se apoderó de él, al constatar que el mayor y más prestigioso de los maniqueos no podía resolver "las cuestiones que lo agitaban" 12 . Incluso termina Agustín convirtiéndose en maestro de letras de Fausto, ya que éste le expresa su curiosidad por conocer lo que Agustín enseñaba a los jóvenes en sus clases de retórica. Lo único que aprendió entonces de Fausto fue su honestidad, porque al exponerle sus interrogantes, el célebre personaje maniqueo reconoció humildemente su incapacidad y su ignorancia: "cuando le hube propuesto mis problemas para su consideración y discusión, se comportó con mucha modestia y no se atrevió a arrimar el hombro a tan pesada carga. Bien sabía él que ignoraba tales cosas y no tuvo reparo en reconocerlo. No era de la laya de otros hombres locuaces que yo había padecido, que pretendían enseñarme, pero no decían nada. Fausto era un hombre de corazón; si no lo tenía enderezado hacia ti, tampoco lo tenía clavado en sí mismo... eso me gustó sobremanera"13.

\footnotetext{
${ }^{9}$ Ídem.

${ }^{10}$ Conf. Libro 5, VI, 3.

${ }^{11}$ Conf. Libro 5, VII, 1.

${ }^{12}$ Conf. Libro 5, VII, 2.

${ }^{13}$ Conf. Libro 5, VII, 1.
} 
En síntesis, Agustín no se deja encandelillar por la elocuencia; tiene preguntas serias que no se resuelven con superficialidad, porque necesitan de un bagaje cultural importante que Fausto no tenía. Fausto no reunía las condiciones intelectuales que la altura de la interrogación de Agustín pedía y por eso su elocuencia no bastó, sino que resultó ser solo un ornato deleitable de verdades ya conocidas que por eso mismo nada aportaron al espíritu inquisitivo de Agustín ${ }^{14}$. Éste aprecia, de todas formas, dos cosas interesantes en Fausto: su manejo de la lengua y su sencillez. Fausto sabe reconocer su ignorancia y está incluso dispuesto a aprender del mismo Agustín. Pero lo más importante es esto: las preguntas hondas que "agitaban" el corazón de Agustín quedan pendientes ${ }^{15}$. Lo obligan a contentarse con un pensamiento que, aunque lo deja insatisfecho, es el único que se le presentaba y con el cual le tocaba hasta ese momento resignarse ${ }^{16}$.

${ }^{14}$ Cabe recordar aquí cómo san Agustín indica en la predicación la necesidad de superar una presentación simple de la fe cristiana (que él mismo identifica con la "fe del carbonero o de los simples") justamente porque hay debate, porque hay herejes cuyas preguntas acicatean la inteligencia del predicador y la de los cristianos en general. Desde ese punto de vista, Agustín reconoce la importancia del error o de la herejía y la necesidad de pensar la fe, de hacerla inteligente y capaz de dar razón de lo que ella afirma: "Nadie investigará los ocultos sentidos de la Escritura, si todos se contentan con la fe del carbonero (Sacramenta enim quae illic latent, nemo discuteret, simpliciore contentus fide); y, por lo mismo, nadie hallaría nada, porque nadie las examinaría sin el acicate de sus difamadores" (Sermón 51, 11). Para las obras de San Agustín, nos valemos en este artículo de la versión de la BAC Obras de san Agustín. La cita señalada se encuentra en el Tomo X, Madrid, 1952, p. 19. De ahora en adelante daremos siempre esta segunda referencia, con el ánimo de facilitar al lector la búsqueda y profundización de estas citas. Citaremos entonces así, por ejemplo: Sermón 51, 11. BAC, Tomo X, p. 19. Cada vez que citemos un tomo nuevo, indicaremos al lector su año de edición.

${ }^{15}$ Vale la pena recordar también aquí lo que narra San Agustín al contar la conversión del famosos retórico romano Victorino, que le fue narrada por su amigo Simpliciano en Roma. Al testimoniar el credo de la fe en público, Victorino no quiso hacerlo a puertas cerradas, como se le concedía a algunos que aún se sentían débiles -indica San Agustín- sino que lo hizo en público. Y san Agustín inserta esta pregunta en su narración: “¿Cómo no hacerlo así, cuando públicamente había enseñado la retórica, que no nos da la salvación?”, Conf. Libro 8, VIII, 5. 16 “... no encontrando por el momento nada mejor que aquello en que ciegamente había dado de cabeza, había resuelto contentarme con ello mientras no apareciera ante mis ojos algo mejor", Conf. Libro 5, VII, 2. Más adelante, en las mismas confesiones, afirma: "Más tarde me extravié en la sacrílega superstición del maniqueísmo, no por estar cierto de que era verdad, sino porque me parecía preferible a otras doctrinas que ciegamente combatía en vez de estudiarlas con piedad y atención", Libro 8, VII, 2.

Para una mejor comprensión de la influencia que Fausto tuvo en la vida de San Agustín, he aquí la siguiente cita:

"Si, dans les Confissions, Augustin faisait preuve d'une sympathie condescendante envers le brave home de Milev, plus tard, quand il aura lu les Capitula, le jugement sera tout autre"... 


\subsection{Su experiencia con Ponticiano}

Habría muchas cosas para comentar aquí, pero por razones de brevedad conviene pasar a la experiencia de Agustín como auditor de san Ambrosio. Al tratar este segundo momento, se podrán, por vía de contraste entre las dos experiencias -encuentro con Fausto y encuentro con Ambrosio- resaltar algunas ideas importantes. No obstante, antes de mencionar a Ambrosio, es útil hacer un breve apunte sobre lo que cuenta san Agustín cuando Ponticiano le habló a él y a su amigo Alipio de su conversión, provocada a su vez por la narración de la vida de San Antonio Abad (251-356). De hecho, cuando comienza dicha narración, san Agustín la anuncia en estos términos: "Contaré ahora cómo me libraste de la esclavitud de las preocupaciones del siglo y cómo rompiste la cadena con que me retenía el apetito carnal. Todo te lo confesaré, Dios mío, mi redentor y mi auxilio" 17 .

Agustín describe los efectos (el impacto) que la escucha del relato de Ponticiano causaba en él: "Y mientras él hablaba tú me hacías retorcerme y entrar en mí mismo, quitándome de mis propias espaldas en las que yo mismo me había puesto. Me ponías frente a frente de mí mismo para que viera mi fealdad, cuán sórdido y deforme era yo, cuán manchado y ulceroso... Ponticiano no me dejaba; continuaba hablado y hablando, y decía lo que tenía que decir. Y tú persistías en enfrentarme a mí mismo y ponías viva luz en mis ojos para que viera mi maldad y la aborreciera. Ya la conocía yo, pero la disimulaba, me convertía en su cómplice y terminaba con sepultarla en el olvido. Pero en ese momento, cuanto mayor atracción sentía por aquellos hombres, de quienes estaba oyendo hablar y cuyos nobles sentimientos los habían llevado a entregarse a ti, tanto más miserable me hallaba comparándome con ellos"18. Vale la pena señalar dos cosas: el que habla, Ponticiano, habla desde su propia vida y su propio proceso de conversión. El que escucha, San Agustín, vive, por medio de la historia escuchada, una llamada de Dios identificada aquí con una confrontación, con un auto-examen que le hace evaluar y revisar su vida

\footnotetext{
“Or, d'un ouvrage à l'autre, l'évêque manichéen change complètement de physionomie. Dans les Confessions, ce n'est qu'un bel esprit, orateur aimable sans doute, mais superficiel: un phraseur à l'esprit vide, à l'éloquence creuse. Dans le Contra Faustum, malgré toutes les réserves et les critiques, ce bel esprit devient un érudit, exégète avisé, vigoureux polémiste: un adversaire avec qui l'on doit compter". Jason David BEDUHN, Augustine's Manichean Dilemma, Vol. 1: Conversion and Apostasy, 373-388 C.E. University of Pennsylvania Press, 2010. pp. 331.

${ }^{17}$ Conf. Libro 8, VI, 1.

${ }^{18}$ Conf. Libro 8, VII, 1.
} 
de forma más sincera y decidida. El discurso no le llega sólo a la inteligencia, le toca la existencia toda, lo persuade abriéndole horizontes de vida nueva que empiezan a sentirse como posibles, realizables y felices. San Agustín queda "conturbado en el rostro y en el ánimo por la bravísima pelea interior que la narración le produjo" ${ }^{19}$. El discurso no ha roto esta vez ninguna ilusión, más bien ha despertado otras; el discurso no lo ha dejado indiferente.

\subsection{Su experiencia como oyente de san Ambrosio}

Se sigue ahora la experiencia de Agustín como oyente de san Ambrosio. En primer lugar, de entrada, hay un elemento del que se beneficia el Obispo de Milán con respecto a Agustín: un prestigio reconocido. Pero Fausto también gozaba de autoridad, y Agustín dice que era el más célebre de los Maniqueos. Esto hay que subrayarlo habida cuenta de lo que en la retórica clásica significa la autoridad del que habla ${ }^{20}$. San Agustín hace ese reconocimiento: “... se me envió a Milán, en donde me recibió tu obispo Ambrosio, renombrado en todo el orbe por sus óptimas cualidades. Era un piadoso siervo tuyo que administra vigorosamente con su elocuencia la grosura de tu trigo, la alegría de tu óleo y la sobria ebriedad de tu vino"21. Esa fama de Ambrosio se completa con una acogida alegre y paternal que el mismo Obispo ofrece a San Agustín ${ }^{22}$.

Y san Agustín reconoce que "empezó a quererlo y aceptarlo. Al principio no como a un doctor de la verdad, pues -agrega Agustín- yo desesperaba de encontrarla en tu Iglesia, sino simplemente como a un hombre que era amable conmigo"23. Aquí conviene insistir en algo importante para la nueva

\footnotetext{
${ }^{19}$ Conf. Libro 8, VIII, 1. Después de formular preguntas alteradas a su amigo Alipio, una vez que Ponticiano se marchó, Agustín se marcha al jardín de la casa en donde estaba y dice: “Allá me encaminó el tumulto de mi pecho, pues allí nadie podía intervenir en la dura lucha en que andaba conmigo mismo, hasta que se produjera un desenlace que tú conocías, pero yo no. Alli me sentí enloquecer de cuerda locura y morir con muerte vital, sabedor del mal que padecía, pero ignorante de la salud que más tarde iba a tener", Conf. Libro 8, VIII, 2. Nosotros ponemos en cursiva.

${ }^{20}$ Según la retórica clásica toda situación de discurso comporta la presencia de tres elementos: El orador, el discurso y el auditorio. Si la calidad del discurso depende de la argumentación formulada, y si la atención al auditorio reposa sobre las emociones suscitadas, la calidad del auditor estriba ante todo en la autoridad poseída. Cfr. AQUIEN Michèle - MOLINIÉ Georges, Dictionnaire de rhétorique et de poétique, Paris, Le Livre de Poche, 1966, p. 7-25.

${ }^{21}$ Conf. Libro 5, XIV, 1.

22 Ídem.

${ }^{23}$ Conf. Libro 5, XIV, 2.
} 
retórica, especialmente la de algunas corrientes, según las cuales, antes de analizar cualquier discurso habría que observar la relación que se establece entre los hablantes. El ámbito de la comunicación no lo configuran sólo las circunstancias culturales (políticas, económicas, etc.) sino también la relación que se produce entre los hablantes ${ }^{24}$. El afecto de Agustín está mezclado con cierta prevención, con cierto afán de probar o de verificar, con cierto espíritu crítico: "Con mucha atención lo escuchaba en sus discursos al pueblo; no con la buena intención con que hubiera debido, sino para observar su elocuencia y ver si correspondía a su fama, si era mayor o menor de lo que de él se decía. Yo lo escuchaba suspenso, pero sin la menor curiosidad ni interés por el contenido de lo que predicaba. Me deleitaba la suavidad de su palabra, que era la de un hombre mucho más docto que Fausto, aunque no tan ameno ni tan seductor en el modo de decir. Pero en cuanto al contenido de lo que el uno y el otro decían no había comparación posible: Fausto erraba con todas las falacias del maniqueísmo mientras que Ambrosio hablaba de la salvación de manera muy saludable" 25 .

Es un atrevimiento comentar estas palabras tan claras, y sin embargo hay que subrayar algunos puntos: si el oyente Agustín escucha con oídos críticos, no por eso deja de apreciar cierta suavidad en la elocuencia de Ambrosio. Pero al fin de cuentas, lo que más le importa es el contenido. Contenido en un principio casi despreciado -sin la menor curiosidad ni interés por el contenido de lo que predicaba-, pero al que fue llevado poco a poco por la calidad de la palabra de un hombre docto, pero que además respaldaba su voz con el testimonio de su vida y con la suavidad del lenguaje. Así, san Agustín es conducido a escuchar a Ambrosio cada domingo ${ }^{26}$. Y aunque sólo se fijaba en el modo en que Ambrosio decía, -agrega Agustín-: “... sin embargo llegaban

\footnotetext{
${ }^{24}$ Evidentemente, no se puede analizar la retórica de san Agustín con los planteamientos de la "nueva retórica". No obstante, nos parece que lo que está en juego en las palabras de San Agustín, al plantear lo que le pasaba al escuchar a San Ambrosio, es el tema de la relación que la escucha de los sermones del Obispo de Milán engendraba en él. Este tema, en una tendencia actual sobre la comunicación, concretamente la llevada a cabo por Paul Watzlawick, es tematizado con una distinción entre el contenido de la comunicación y la relación que se da entre los hablantes. Para un presentación de esta tendencia ver: SICILIANI José María, Contar la Buena Nueva, Bogotá, Ed. Antropos, 2012, p. 23-41.

${ }^{25}$ Conf. Libro 5, XIV, 2.

26 "Cada domingo lo escuchaba yo cuando exponía tan magistralmente ante el pueblo la palabra de verdad; y cada vez crecía en mí la persuasión de que era posible soltar el nudo de todas aquellas calumniosas dificultades que los maniqueos levantaban contra los sagrados libros", Conf. Libro 6, III, 3.
} 
a mi alma, envueltas en las bellas palabras que apreciaba, las grandes verdades que despreciaba, y no podía yo disociarlas. Y mientras abría mi corazón para apreciar lo bien que enseñaba las cosas, me iba percatando muy poco a poco de cuán verdaderas eran las cosas que enseñaba. Gradualmente fui derivando a pensar que tales cosas eran aceptables"27.

En la forma de las palabras se iba destilando imperceptiblemente un contenido profundo de fe, una verdad sobre Dios que pronto acaparará todo el corazón de San Agustín. Porque en la predicación de Ambrosio, como en toda auténtica predicación, eran indisociables la suavidad de las palabras y la solidez del mensaje de salvación en Cristo. Y esa articulación entre fondo y forma, esa combinación perfecta entre lo que se dice y la manera como se dice, implicaba en la predicación del Obispo de Milán la aplicación de un método de lectura de la Sagrada Escritura que el mismo Agustín va aprendiendo domingo a domingo, al escuchar los sermones ambrosianos: “...tras haber oído las explicaciones de Ambrosio una vez y otra y muchas más, me encontraba con que Él resolvía satisfactoriamente algunos enigmas del Antiguo Testamento entendidos por mí hasta entonces de una manera estrictamente literal, que había matado mi espíritu ${ }^{28}$. Agustín como oyente no solo capta la suavidad del lenguaje y la solidez del mensaje que dicho lenguaje vehicula, sino que, además, descubre un método de interpretación bíblica. Enorme demostración de lo que sucede en la predicación o de lo que podría suceder si se la tomara más en serio ${ }^{29}$.

\footnotetext{
${ }^{27}$ Conf. Libro 5, XIV, 1.

${ }^{28}$ Conf. Libro 5, XVI, 1. "Me alegraba también de que los viejos escritos de la ley y los profetas no se me dieran a leer con mis antiguos ojos, que tantos absurdos veía en ellos cuando yo redargüía a tus santos por errores que ellos nunca profesaron. Y grande era mi contento cuando oía frecuentemente a Ambrosio decir con énfasis que la letra mata y el espíritu vivifica (2Cor 3, 5). Así, descorriendo espiritualmente el velo místico, explicaba algunos pasajes de la Escritura que entendidos en forma literal estricta suenan a error; y al explicar de esta manera nada decía que pudiera molestarme aun cuando dijese cosas de cuya verdad no me constaba todavía". Conf. Libro 6, IV, 2.

${ }^{29}$ En los libros VI, VII y VIII Agustín describe su conversión definitiva, que pasó por luchas interiores tremendas y un proceso catecumenal importante, en que se integraron el estudio, la reflexión y los diálogos. Además de la predicación se dieron otros aspectos, algunos de los cuales conviene recordar aquí: la oración y acción de su propia madre, Mónica, sobre todo para que abandonara sus relaciones afectivas desordenadas, la formación, el diálogo con Ambrosio y sus amigos Alipio y Nebridio. Conf. Libro 6, VII, 1.
} 


\subsection{La retórica homilética en el contexto postmoderno}

El testimonio de San Agustín es sumamente ilustrativo de lo que se podría llamar una teología de la predicación. Pero hay que ubicar brevemente dicha teología en un marco epistemológico-teológico que anima el trabajo investigativo del que surgen estas páginas. Se trata de la "Teología Práctica". Se entiende dicho concepto de la siguiente manera: "es una forma de producir conocimiento teológico que arranca de las prácticas de los cristianos en el mundo como materia prima que, analizada con las herramientas de las ciencias humanas y sociales, es luego interpretada a la luz de la Palabra de Dios, de la Tradición eclesial y de la teología. Esta teología quiere, al fin de su recorrido metodológico, retornar a las mismas prácticas para potenciarlas, cualificarlas, orientarlas interrogándolas ${ }^{30}$. En esa última fase de su proceso, que tiene que ver mucho con la dimensión martirial de la comunidad creyente, es decir con la evangelización ${ }^{31}$, la teología práctica se toma muy en serio el diálogo con la pedagogía, con las ciencias de la comunicación y con las ciencias estratégicas, porque las considera condición necesaria para ofrecer una palabra pertinente o brindar orientaciones críticoconstructivas a las prácticas de los creyentes en el mundo.

Justamente, la "Teología práctica" se ubica en el plano de la comunicación y recepción de la fe en el mundo actual, y por eso le preocupa principalmente el asunto de la pertinencia de una palabra evangelizadora para los hombres de hoy; una palabra susceptible de ser escuchada y acogida como una propuesta con sentido, digna de ser asumida como un acto humanizador y responsable en los tiempos presentes ${ }^{32}$. La famosa definición de san Anselmo según la cual la teología es la Fides quaerens intellectum, se transforma, en el marco de esta

\footnotetext{
30 "Las prácticas son a la vez el punto de partida y el punto de llegada de los procedimientos discursivos. El interés primero por las prácticas contribuye a hacer de la teología práctica un campo de estudios originales. Ningún otro campo de estudios teológicos adopta las prácticas como objeto material, exceptuando quizás la teología moral que lo hace por otro camino. La teología práctica se interesa en todas las prácticas humanas en la medida en que ellas son actual o virtualmente lugar de la actividad de Cristo en el mundo", Marcel Viau, "De la théologie pastorale á la théologie pratique", en Gilles Routhier - Marcel Viau (Dir.), Précis de théologie pratique, París - Bruselas - Montreal, ediciones L'Atélier - Lumen Vitae - Novalis, 2007'12, p. 44. Al escribir estas líneas sobre la teología práctica nos inspiramos en este texto.

${ }^{31}$ Seguimos aquí a E. Alberich que distingue cuatro formas fundamentales de la visibilidad eclesial: la diakonia, la koinonia, la martyria y la leitourgia. Cfr. ALBERICH Emilio DERROITTE Henri - VALLABABARAJ Jérôme, Les fondamentaux de la catéchèse, Bruselas - Quebec, Ed. Lumen Vitae - Novalis, 2006, p. 55.

${ }^{32}$ San Agustín diría: hacerse escuchar benévola, animada y obedientemente.
} 
teología práctica, en fides quaerens verbum efficax. Porque no importa ahora sólo comprender, sino comunicar bien y eficazmente (diríamos con Agustín: ilustrando, deleitando y conmoviendo), en la sociedad contemporánea, el contenido de la fe. Y porque "el discurso es la forma más elevada de una práctica en la cual el intellectus está en operación"

Ahora bien, la práctica abordada aquí es la compleja tarea llamada predicación. Y como toda práctica, la predicación se comprende en la medida en que es puesta en un discurso que la explicita. A partir de esta premisa, la teología de la predicación es un intellectus que se pronuncia -discursivamente- sobre el acto de comunicar el evangelio en la homilía ${ }^{34}$. Es una teología que busca aclarar esa práctica compleja que no solo compete al predicador, como si, por un lado, el acto de comunicación dependiera únicamente de él, o como si, por otro lado, el acto de la predicación interesara exclusivamente al ministerio ordenado y no fuera tarea de todo cristiano que ha asumido la fe en Jesucristo ${ }^{35}$. En todo caso, si la teología práctica se da como objetivo primero la producción de un discurso pertinente para el mundo actual ${ }^{36}$, y si la predicación -en particular la que se produce por medio de sermones y homilías en la liturgia eucarística- está animada por una clara y pública intención retórica o comunicativa, hay que decir entonces que esta confluencia de intencionalidades permite ubicar muy bien a la homilética dentro de este campo ${ }^{37}$ de la teología práctica ${ }^{38}$.

\footnotetext{
${ }^{33}$ Marcel Viau, Op. Cit., p. 44.

${ }^{34} \mathrm{O}$ en muchas de las otras formas discursivas que puede revestir la predicación en la comunidad creyente, como por ejemplo en la predicación catequética, en la predicación escolarizada a través de la clase de Religión, etc.

${ }^{35}$ Ciertamente en estas líneas pensamos sobre todo en la predicación homilética, que sí es, según la legislación eclesial del Cogido de Derecho Canónico (CIC), tarea propia y prioritaria del obispo, del presbítero o del diácono. Cfr. CIC $767 \S 1$.

${ }^{36}$ M. Viau, Op. Cit., p. 45.

${ }^{37}$ Según M. Viau, definir la teología práctica como un campo teórico implica los siguientes elementos: no depender o salir de un cuerpo articulado, como en las ciencias puras, por ejemplo; un conjunto de principios y de métodos salidos de varias disciplinas en un contexto de formación, muy frecuentemente universitario y de investigación... unas teorías salidas principalmente de las prácticas, M. Viau, Op. Cit., p. 44-45.

${ }^{38}$ Los Manuales importantes de Teología Practica aparecidos en los últimos 10 años incluyen casi siempre la homilética como un área de estudio de la Teología Práctica. Ver Gilles Routhier-Marcel Viau (Dir.), Précis de théologie pratique, Op. Cit., el amplio capítulo dedicado a la proclamación, p. 253-468; Bernard Kaemps (Dir.), Introduction à la théologie pratique, Estrasburgo, Presses Universitaires de Strasbourg, 1997, el capítulo sobre la homilética de Bernard Reymond, p. 109-126. Ver también: Michel Deneken - Elisabeth Parmentier, Por quoi précher. Plaidoyer catholique et protestant pour la prédication, Génova, ed. Labor et Fides, 2010.
} 
Ahora bien, a la luz de una distinción entre lenguaje y discurso, tal como lo hace la lingüística contemporánea ${ }^{39}$, producir teología en esta perspectiva es desarrollar un discurso en el que intervienen tres dimensiones: la dimensión material (los signos o las palabras que representan), la dimensión de designación del objeto (el objeto representado) y la dimensión contextual que remite a otros signos lingüísticos y culturales y que tienen con ver con el intérprete y la relación que se produce entre los que hablan. En realidad el lenguaje se vuelve discurso sólo en el contexto de una interacción entre seres humanos hablantes, que usan el lenguaje dentro de un sistema que facilita la comunicación y el desciframiento de significados. Dicho rotundamente, no hay discurso sino allí donde hay intercambio entre personas en un contexto determinado. A la larga eso es lo único que hay, porque el lenguaje en abstracto, en cierta forma sigue siendo una abstracción y así nunca se encuentra en la vida concreta.

Esta perspectiva es fundamental para la teología práctica y para la homilética. Porque en última instancia buscar a través de la teología un verbum efficax o buscar en la homilía conmover al auditor es tomar conciencia de la importancia de ampliar el concepto habitual de discurso (de sermón), y caer en la cuenta, lúcidamente, que lo que está en juego es algo profundo y vasto: se trata ni más ni menos de tocar el corazón o de alcanzar las creencias ${ }^{40}$ profundas para renovarlas según la mente de Cristo. "Todo el desafío consistirá en hacer pasar el oyente de la duda a la creencia, es decir, de una situación problemática $<$ indeterminada $>$ a una situación $<$ determinada $>$, fija, estable. Ese proceso se

\footnotetext{
${ }^{39}$ Hoy, sobre todo con base en la lingüística pragmática, no se considera sólo la existencia de signos (el código o los significantes), ni el discurso (el significado) que produce la articulación de los signos lingüísticos, sino que se contempla también la intención comunicativa del sujeto que habla y el contexto en el que se produce la enunciación. "Otra tradición, la de Peirce y Morris, define el signo como una unidad lingüística con tres dimensiones: la permanente dimensión material (el representamen), la dimensión de designación del objeto (el objeto), la dimensión de reenvío a otros signos (el intérprete)". Marcel Viau, "De la théologie pastorale à la théologie pratique", Op. Cit., p. 45-46.

${ }^{40}$ Según Marcel Viau la creencia es algo más que las ideas: "El estado de creencia es esa parte dinámica de nuestro ser que hace que continuemos viviendo. Sin creencia, moriríamos. Por consiguiente, la creencia no es una simple opinión subjetiva o una idea más o menos bien fundada que tendría necesidad de pruebas irrefutables para ser tomada en serio. Ella es mucho más potente porque provoca en nosotros un sentimiento más fuerte y estable que las ideas. El acto psíquico que la saca a la luz es de naturaleza radical, absoluta, del orden del todo o nada. Creemos o no creemos en esto o en aquello. En esta materia no hay semi-medidas". Marcel Viau, "De la théologie pastorale à la théologie pratique", Op. Cit., p. 49. "La creencia es una disposición a actuar", p. 49-50.
} 
llama una argumentación y es la retórica el mejor útil en las circunstancias" ${ }^{\prime 1}$. La pregunta de fondo que hay aquí es esta: ¿Cómo se produce el proceso que hace pasar a un individuo de la duda a la creencia? ${ }^{42}$ Lo visto en la experiencia personal de San Agustín puede ayudar a intuir la importancia de la retórica en la predicación. Porque, en definitiva, en el ámbito de la teología práctica y en el de la predicación, no se trata tanto de dar cuenta de verdades eternas sino de producir un impacto sobre el interlocutor. Se trata, en ambos casos, más bien de una puesta en movimiento y no sólo de una instrucción conceptual. Y eso, para lo cual es utilísima la retórica, es lo que seguidamente se verá, haciendo algunos comentarios al libro IV de la Doctrina Christiana de San Agustín.

\section{Observaciones sobre el Libro IV De Doctrina Christiana}

Después de las anotaciones sobre Agustín como oyente de sermones, conviene mirar ahora lo que en el famoso libro IV de la Doctrina cristiana el Obispo de Hipona señala sobre la retórica. Éste no es un libro sistemático ${ }^{43}$, pero contiene, tal como ha sido valorado hasta nuestros días por la homilética cristiana $^{44}$, las orientaciones fundamentales de una comprensión sobre el puesto de la retórica en la teología de la predicación y en la práctica concreta de la homilía. San Agustín resume al comienzo del libro cuarto todo el contenido del texto De Doctrina Christiana: "Dos son las cosas en que se funda todo estudio de las Escrituras: el modo de hallar las cosas que se han de entender y el modo de exponer las ya entendidas" ${ }^{\prime 4}$. He aquí entonces algunos puntos que ofrecen una clave de entrada a los sermones de San Agustín, que de alguna forma son la puesta en práctica de todas estas reflexiones sobre el modo de exponer las Escrituras en la predicación cristiana.

${ }^{41}$ Ibídem, p. 50.

42 Ídem.

${ }^{43}$ No es sistemático en el sentido de no presentar la materia retórica en sus diferentes aspectos, tal como se concebía en la antigüedad. En efecto, el mismo Agustín afirma al lector, al comienzo del libro IV de La doctrina cristiana, que no espere de ese libro que sea un curso de retórica. San Agustín, Sobre la Doctrina Cristiana, Madrid, BAC, 1957. Libro IV, 2. (Página 263). De ahora en adelante abreviaremos las citas tomadas de este libro con la sigla DC. Y puesto que el libro está dividido en numerales, añadiremos el número correspondiente del cual extraemos la cita o la idea.

${ }^{44}$ A manera de ejemplo, un libro clásico del siglo XX sobre la oratoria cristiana recoge expresamente el legado retórico agustiniano: SERTILLANGES D, El orador cristiano, Madrid Buenos Aires, Ediciones Studium, 1954, p. 249-273.

${ }^{45}$ DC 1. 
Es posible articular estas observaciones en torno a la pregunta central del libro: ¿Cuál es la utilidad de la retórica ${ }^{46}$ en la predicación cristiana? Y lo primero que dice Agustín es que la retórica sirve para defender la verdad y la mentira, para persuadir de las cosas buenas o de las malas. La forma de la afirmación es significativa en sus detalles: ¿Quién dirá que los que inculcan la mentira han de saber exponerla con brevedad, claridad y verosimilitud y los otros que cuentan las verdades de tal modo lo han de hacer que produzca hastío el escucharlas, trabajo el entenderlas y por fin repugnancia el adoptarlas?... ¿Quién dirá que aquellos al hablar moviendo y empujando al error los ánimos de los oyentes, los han de aterrar, contristar, alegrar y exhortar con ardor; y éstos defendiendo la verdad han de dormitar con languidez y frialdad?... ¿Por qué los buenos no se dedican a conseguirle -el arte del discurso-para que sirva a la virtud...? ${ }^{47}$. Cada una de las palabras que emplea Agustín (sustantivos o verbos) es densa en contenido: brevedad, claridad, verosimilitud, hastío, dificultad, repugnancia, mover, empujar, aterrar, contristar, alegrar, exhortar, dormitar. Si se tomara sólo la palabra brevedad se podría decir: la retórica sirve para exponer el contenido de la Sagrada Escritura brevemente, sin necesidad de extensos discursos fastidiosos ${ }^{48}$. A la brevedad se puede agregar la claridad y la verosimilitud, que a su vez contrastan con el aburrimiento que llega hasta el adormilamiento en los sermones. Pero hay otros aspectos aún más interesantes en el libro IV De Doctrina Christiana.

\footnotetext{
${ }^{46}$ Nos permitimos recordar al lector que aquí siempre entendemos retórica como "el arte del discurso persuasivo". Ver DC 3.

${ }^{47} \mathrm{DC} 3$.

${ }^{48}$ Hay que advertir que la noción de brevedad (brevitas) en la retórica clásica no se refiere necesariamente a la concisión o al laconismo (concisión extrema). Cabe también señalar que la brevedad podía referirse a algunas de las partes de la retórica clásica (por ejemplo a la elocutio, la narratio, la dispositio...). En cada una de ellas podía tomar una configuración particular que no se identifica necesariamente con la poquedad de palabras, la cual, incluso, podía convertirse en un defecto (detractio) que haría oscuro al discurso. Por ejemplo, en la narración, -dependiendo incluso del tipo de narración en cuestión (abierta, probable $u$ ornada)- la brevedad adquirirá matices diversos: "La utilitas es el interés parcial en la persuasio del juez, persuasión que se ha de alcanzar por medio de la narratio credibilis. Utilitas y brevitas imponen la omisión de aquellas partes de la narración que son desfavorables al interés parcial; la brevitas impone además que se omita todo aquello que no favorezca positivamente ese interés (a menos que sea necesario por causa de la narratio aperta". LAUSBERG H. Manual de retórica literaria. Fundamentos de una ciencia de la literatura. Tomo I. Madrid: Gredos, 1966, p. 275. Cfr. MOLINIÉ G. Dictionnaire de rhétorique. París: Le Livre de Poche, 1992: p. 71-73. Estos matices sobre la brevedad pueden ayudar a entender el carácter poco breve de los sermones de san Agustín.
} 
Esencialmente, afirma san Agustín que la retórica cristiana sirve para lograr tres objetivos fundamentales: ilustrar, emocionar y conmover -o instruir, deleitar y conmover" ${ }^{49}$. "El doctor y expositor de las Escrituras divinas, como defensor que es de la fe y develador del error, debe enseñar lo bueno y desenseñar lo malo, y asimismo mediante el discurso apaciguar a los contrarios, alentar a los tibios y enunciar a los ignorantes de qué se trata, y qué deben esperar. Después que haya hecho a sus oyentes benévolos, atentos y dóciles, habrá de llevar a cabo el asunto -de la predicación- conforme lo pidiere la causa" ${ }^{50}$. Cada situación -y ese es un deber imperioso del orador: discernir lo que más necesita y conviene a un auditorio determinado- el orador cristiano debe identificarla lo más precisamente posible, porque algunas veces la comunidad necesita más aliento que doctrina, otras necesita más conmoción que empuje al compromiso, otras más claridad en las ideas que deleite en las palabras ${ }^{51}$.

Por esta razón es necesario que el que afronta el cargo de la predicación busque la elocuencia, aunque ésta no sea superior a la sabiduría. En efecto, importa más hablar sabiamente que elocuentemente ${ }^{52}$. Sin embargo, si es verdad que puede haber una elocuencia sin sabiduría, tanto más peligrosa cuanto que hace pensar que la belleza del discurso es lo que garantiza su veracidad, san Agustín recuerda que los retóricos clásicos habían enseñado que "la sabiduría sin elocuencia aprovecha poco a las naciones"53. De ahí que el ideal sea aunar la sabiduría a la elocuencia, unir la suavidad o el deleite del lenguaje elocuente a la verdad sólida de la fe: "Pues así como muchas veces deben tomarse las cosas amargas por ser saludables, así también siempre debe

\footnotetext{
49 "Dijo, pues, un maestro de elocuencia, y dijo la verdad, que el orador de tal modo debe hablar que enseñe, deleite y mueva. Y añadió después: <el enseñar es propio de la necesidad, el deleitar de la amenidad y el mover de la victoria. De estas tres cosas la primera que se dijo, esto es, la necesidad de enseñar, se halla situada en las cosas que decimos; las otras dos en el modo de decirlas”. DC 27. Ver también el número 34.

${ }^{50} \mathrm{DC} 6$.

51 "Si los oyentes que escuchan deben ser enseñados, dado caso que lo necesiten, ha de hacerse por medio de la narración, a fin de dar a conocer el asunto de que se trata. Más para que lo dudoso se haga cierto se ha de reaccionar aduciendo pruebas. Pero si los oyentes deben ser excitados más bien que enseñados, a fin de que no sean remisos en cumplir lo que ya saben y presten asentimiento a las cosas que confiesan verdaderas, entonces se requieren mayores arrestos de elocuencia. Aquí son necesarios los ruegos y las súplicas, las reprensiones y amenazas y todos los demás recursos que sirven para conmover los ánimos", DC 6.

52 DC 7. "Los que hablan con elocuencia son oídos con gusto, los que hablan sabiamente con provecho", DC 8.

${ }^{53}$ DC. 7.
} 
evitarse lo dulce que es pernicioso. ¿Y qué cosa mejor que una saludable suavidad o una suave salubridad? En este caso cuanto más se apetece la suavidad, tanto más fácilmente aprovecha la sabiduría" ${ }^{54}$.

Esto permite a San Agustín formular el argumento más importante para promover el uso de la retórica en la predicación cristiana. Lo expresó de la siguiente forma: 'Es en la misma Sagrada Escritura donde el predicador encuentra la presencia de la retórica' ${ }^{55}$. Ahora bien, en la línea de pensamiento que viene elaborando San Agustín en torno a la elocuencia y la sabiduría, la Sagrada Escritura es el texto donde mejor confluyen estas dos realidades: "Ahora tal vez pregunte alguno si nuestros autores, cuyos escritos divinamente inspirados componen nuestro canon de muy provechosa autoridad, han de ser llamados solamente sabios o también elocuentes. Fácilmente se descubre esta cuestión por lo que a mí toca y los que conmigo sienten lo que digo. Donde les entiendo, me parece que no puede darse otra cosa más sabia ni más elocuente" ${ }^{" 56}$.

Hay pues una presencia real de la retórica en la Biblia, que san Agustín incluso califica de particular, de original, y con unos rasgos propios: "Pero lo que en esta elocuencia me deleita más de lo que puede ponderarse, no es lo que tienen de común nuestros autores con los oradores y poetas gentiles; lo que más me aturde y maravilla es que de tal modo usaron de la elocuencia nuestra, moldeándola con otra cierta y propia suya, que ni faltó en ellos ni tampoco descolló; pues no era conveniente que desaprobasen la mundana ni que hicieran ostentación de ella" 57 . Lo que caracteriza a esta elocuencia bíblica es una cierta naturalidad en que se articulan espontáneamente la sabiduría y la belleza; una elocuencia gobernada por la sabiduría, que la sigue y acompaña inseparablemente: "En los pasajes en que los doctos la descubren se dicen tales cosas que las palabras con que se dicen no parecen empleadas por el que las dice, sino como naturalmente unidas a las cosas, como si se nos quisiera dar a entender que la sabiduría sale de su misa casa, es decir, del corazón del sabio, y que la elocuencia como criada inseparable la sigue sin ser llamada". ${ }^{58}$

${ }^{54}$ DC. 8.

${ }^{55}$ Este argumento es también esgrimido hoy por los estudiosos de la exégesis retórica, que aducen el mismo dato como razón para emplear este método exegético en el estudio de la Biblia. Así lo reconoció también la Pontificia Comisión Bíblica. Cfr. La interpretación de la Biblia en la Iglesia, Madrid, PPC, 1994, p. 40-41.

${ }^{56}$ DC 9. San Agustín afirma que las figuras de estilo (sobre todo de aquellos que las usan y se jactan de ellas) están en la Escritura.

${ }^{57} \mathrm{DC} 10$.

${ }^{58}$ DC 10. Ver los ejemplos de retórica bíblica que analiza Agustín en los números 11-21. 
Si la retórica está en la Sagrada Escritura, de ahí no se sigue que el estilo de la Sagrada Escritura tenga que ser completamente empleado por los predicadores. Porque en la Biblia hay cierta oscuridad ${ }^{59}$ que no es recomendable al predicador, sobre todo si éste quiere enseñar o ilustrar. Cuando ese es el objetivo, lo mejor es hacerse entender lo más netamente posible, incluso usando palabras del vulgo que permitan captar de forma diáfana lo que se enseña ${ }^{60}$. Pero ya se ha visto, dado que el objetivo del orador cristiano es triple, incluso cuando ilustra o enseña no debe descuidar el deleite. ¿Por qué? Porque enseñar o "hacer descubrir lo que estaba oculto" 61 , "si se hace esto toscamente el fruto de la enseñanza llegará a muy pocos: a los que desean saber las cosas que deben aprenderse aunque se digan con estilo bajo o inculto ${ }^{62}$. Ciertamente los que se preocupan de la verdad de las palabras y no de la belleza de las palabras solamente, aunque sean pocos, son los más ingeniosos. Pero ese criterio de número no lo desprecia san Agustín: porque el orador no busca solo tocar a los ingeniosos en su auditorio sino a todos. Por eso, si la predicación tosca pero verdadera se puede comparar a una llave de madera que abre una puerta por donde queremos entrar, y por eso es más útil que una de oro que no funciona, o si se puede comparar la predicación con el alimento, que aunque no esté sazonado de todas formas alimenta, es innegable reconocer que es mejor, para que la mayoría lo deguste y coma, ponerle un poco de condimento. Y eso, nada menos que eso, es lo que agrega la elocuencia a la enseñanza: hace que puedan vivir los que más tienen desganas porque se les hace apetecible la comida ${ }^{63}$.

${ }^{59}$ Cfr. DC 22.

${ }^{60}$ San Agustín da incluso algunos ejemplos de palabras que se pueden prestar a confusión, sobre todo a unos oídos africanos que no distinguen de vocales breves y largas, y que podrían no distinguir la equivocidad de ciertas palabras como os que puede ser el nominativo de boca o de hueso en la lengua latina. (Os, ossis, $n$ : hueso / Os, oris, $n$ : boca, rostro). Ver DC 24.

${ }^{61}$ DC 25.

${ }^{62}$ La hermosa afirmación de San Agustín continúa así: “..."Y como se deleita si le hablas con amenidad, igualmente (observarás que) se mueve si ama lo que le prometes, teme lo que le amenazas, odia lo que le reprendes, abraza lo que le recomiendas, se duele de lo que le inculcas digno de dolor, se alegra de lo que le propones como objeto de alegría, se conduele de aquellos que le presentas como dignos de misericordia ante sus ojos, huye de aquellos a quienes les has propuesto con terror que se aparte lie ellos, y, por fin, si hace caso de todos cuantos medios puede emplear una gran elocuencia para conmover los ánimos de los oyentes, no para enseñarlos qué deban hacer, sino para que ejecuten lo que ya saben que debe ejecutarse", DC 27.

${ }^{63}$ Cfr. DC 26. Nos permitimos sugerir aquí el hermoso texto del Profesor A. Fossion que propone el trabajo catequético como una proposición que hace a Dios deseable: FOSSIÓN André, Dieu désirable. Proposition de la foi e initiation, Bruselas, Ed. Lumen Vitae, 2010. 
Al respecto afirma claramente san Agustín del orador: "Si además -de enseñar- quiere deleitar o mover a los que enseña, no es indiferente el modo como hable; para conseguirlo, interesa el modo de decirlo. Así como se ha de deleitar al auditorio a fin de que atienda a lo que oye, del mismo modo se le ha de convencer, para que mueva a ejecutar lo que ha oído. Y como se deleita si le hablas con amenidad, igualmente (observarás que) se mueve si ama lo que le prometes..." ${ }^{64}$. En realidad el fin último del predicador es mover el ánimo. Es verdad que nadie puede hacer lo que ignora, de ahí la importancia de la enseñanza. Pero en la perspectiva retórica, en la perspectiva comunicativa inherente a la Palabra de Dios, al servicio de la cual está el predicador, el fin último es la acción: mover a la acción: “¿Qué valen, en efecto, estas dos cosas para el hombre que confiesa la verdad y alaba la elocuencia, pero no da su asentimiento, siendo así que a esto solo mira la intención del orador en las cosas que dice para persuadir?" 65 .

Cabe notar que la intención del orador es clara y contundentemente definida aquí, y sin ninguna vergüenza. Según esta intencionalidad oratoria, el predicador cristiano quiere conmover, quiere empujar a la acción ${ }^{66}$. Y para esto está la elocuencia. Porque hay quienes admiten la verdad de lo que se dice y se deleitan en la calidad del modo en que se $\operatorname{dice}^{67} \mathrm{y}$, no obstante, no se mueven o no dan su asentimiento. La relación con este tipo de oyentes es como una batalla en que el orador ha de vencer: "Conviene pues que el orador sagrado cuando aconseja alguna cosa que debe ejecutarse, no sólo enseñe para instruir y deleite para retener la atención del auditorio, sino también mueva para vencer”"68. Y

\footnotetext{
${ }^{64}$ DC 28.

${ }^{65}$ DC 29.

${ }^{66}$ San Agustín no deja de precisar esta intencionalidad en otros pasajes: "Como el oficio general de la elocuencia es, en cualquiera de estos tres géneros, hablar aptamente para persuadir, y el fin es persuadir con la palabra lo que se intenta; en cualquiera de estos tres géneros habla sin duda el elocuente como conviene para persuadir, pero a no ser que persuada, no consigue el fin de la elocuencia. Persuade el orador en el estilo sencillo, que es verdad lo que dice; persuado en el sublime para que hagan las cosas que se conocen deben ser hechas y no se ponen en práctica; persuade en el modo moderado, que habla bella y elegantemente; pero ¿qué necesidad tenemos de este fin?... Nosotros ordenamos este fin a otro fin, es decir, que lo que pretendemos hacer cuando empleamos el elevado, esto mismo lo pretendemos en este (moderado), a saber, que se amen las buenas costumbres y se eviten las malas", DC 55.

67 “Conviene, pues, que el orador sagrado cuando aconseja alguna cosa que debe ejecutarse, no sólo enseñe para instruir y deleite para retener la atención del auditorio, sino también mueva para vencer", DC 29.

${ }^{68}$ DC 29.
} 
la victoria no se logra con una buena enseñanza ni con el simple deleite de una normal facundia. "Porque a quien ni la verdad demostrada hasta llegar a confesarla, ni la amenidad del lenguaje le movió, no queda otro remedio para reducirle al asentimiento que la majestad de la elocuencia" ${ }^{69}$.

En este orden de ideas, siguiendo a los oradores clásicos, especialmente a Cicerón, san Agustín especifica que a cada uno de los tres objetivos de la oratoria cristiana (enseñar, deleitar y mover) corresponde un modo de decir. Esto es lo que realmente define a la elocuencia: "Aquel será elocuente que pudiere decir las cosas pequeñas con sencillez, las medianas con moderación y las grandes con sublimidad ${ }^{70}$. Y sin embargo, el Obispo de Hipona precisa que el orador cristiano, desde el púlpito, siempre está ventilando cosas grandes, porque sus discursos tratan de la vida eterna y eso es el mayor de los asuntos ${ }^{71}$. De ahí se podría entonces deducir que, en principio, el predicador cristiano tendría que abordar todos sus temas principalmente con el estilo sublime; estilo que busca sobre todo mover, como ya se ha visto. No es esa, sin embargo la posición de san Agustín: "Aunque el autor cristiano debe decir cosas grandes, no siempre ha de decirlas en estilo elevado; sino que para instruir usará el estilo llano; para alabar o vituperar, el moderado; al tratar de algo que debe hacerse, si hablamos con los que deben hacerlo y se niegan a ello, entonces las cosas grandes se deben decir con estilo sublime y conveniente para doblegar los ánimos"72.

El principio que guía a Agustín en esta distinción es el de la variedad, que depende del asunto tratado: "Nadie piense que el mezclar esta clase de estilos sea opuesto a las reglas de la retórica; es más, siempre que pueda convenientemente ejecutarse se ha de variar la dicción con las clases de estilos. Pues cuando se alarga el discurso en un solo estilo conserva al auditorio menos atento"73. Si es verdad que es el estilo sublime el que facilita el fin último de la predicación, este necesita intercalarse con los otros dos modos (estilo llano y moderado),

\footnotetext{
${ }^{69}$ DC 29.

70 DC 34. San Agustín comenta esa frase del orador romano (Cicerón) escribiendo: "Será elocuente aquel que para enseñar puede decir las cosas pequeñas con sencillez; para deleitar, diga las cosas medianas con moderación; y para mover, exponga las grandes con grandilocuencia", DC 34.

${ }^{71}$ Ver los bellos argumentos que al respecto presenta san Agustín en DC 35.

72 DC 38. "Algunas veces sucede que de una misma cosa que es grande en sí misma se habla llanamente, si se enseña; moderadamente, si se alaba; y elevadamente, si se impele al alma que estaba alejada de ella que se convierta", DC 38.

${ }^{73}$ DC 51.
} 
para que no languidezca y se entibie la atención de los fieles ${ }^{74}$. Lo importante es saber precisar cuál es el estilo que ha de usarse en determinada situación y como mezclar la moderación y la sencillez con lo sublime, de tal forma que éste último aparezca en relieve sobre el telón de fondo de los dos primeros ${ }^{75}$.

Si hay algo importante para determinar esta necesidad de conmover, la percepción que el orador tenga de lo que se está produciendo en el auditorio es de primera importancia. En efecto, mirar a los ojos al auditorio -en lugar de mirar siempre o exclusivamente al techo por ejemplo-, es una actitud que favorece el contacto y la cercanía con los auditores. Agustín, consciente de la importancia de la mirada del predicador, indica que éste no puede estar seguro de haber logrado su objetivo (mover) hasta no percibir ciertos signos en los oyentes: "El estilo elevado, por su mismo peso, las más de las veces oprime las voces, pero exprime las lágrimas"76. Él mismo cuenta lo que vivió en una oportunidad en Cesarea de Mauritania, donde los miembros de esa ciudad se mataban por una vieja y cruel costumbre. Hasta que Agustín no vio, cuando les predicaba, que lloraban, no sintió que había vencido y que la costumbre sería desterrada, como efectivamente pasó después ${ }^{77}$.

Lo importante es, al fin de cuentas, tener conciencia que la claridad, el deleite y la fuerza conmovedora (la performatividad diríamos hoy con la lingüística pragmática) de la predicación no pertenecen a un solo estilo. En cada uno de ellos hay que combinar esas cualidades para que el objetivo final pretendido por el orador cristiano se cumpla ${ }^{78}$. Estas son las cualidades esenciales que deben caracterizar la predicación cristiana, en conformidad con la Biblia misma, en diálogo con la retórica y con el apoyo de la lectura y escucha de los grandes oradores de la rica Tradición cristiana. A estos rasgos se añaden otros elementos importantes: la oración del predicador: éste ha de ser "antes varón de oración que de peroración"79, porque Dios es quien conoce los corazones, Dios es quien da crecimiento, Dios mismo es en última instancia quien habla por nosotros, y el predicador no hace otra cosa sino derramar lo que bebió y exhalar de lo que se llenó ${ }^{80}$. Junto a esta vida de oración está la

\footnotetext{
74 Ídem.

${ }^{75}$ DC 52.

${ }^{76}$ DC 54.

${ }^{77}$ DC 53.

${ }^{78}$ Cfr. DC 56-58.

${ }^{79}$ DC 32.

${ }^{80}$ Idem.
} 
coherencia de vida, simplemente porque "se oye con más obediencia al que

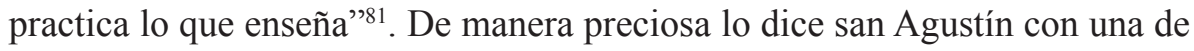
esas frases lapidarias que él sabe labrar: "Lo que a mí me mandas, ¿por qué no lo haces tú? De aquí procede que no oigan obedientemente al que no se oye a sí mismo, y que desprecien junto con el mismo que les habla, la palabra de Dios que les predica" 82 . Junto a la vida de oración y a la coherencia de vida, señala por último san Agustín la prioridad que tiene la verdad de la doctrina sobre la pulcritud de las palabras. Porque el orador no puede ser esclavo de las palabras. No se puede admitir "que el orador sea un mero lacayo de las palabras, sino que las palabras sirvan al orador" ${ }^{83}$.

\section{La constatación de la insipidez de la predicación homilética actual}

Una vía para sustentar la realidad de una crisis de la homilía hoy es recurrir a los siguientes soportes: en primer lugar, la predicación, desde los orígenes y a lo largo de la historia de la Iglesia, ha sido una tarea exigente que debió renovarse constantemente en sus contenidos y en sus métodos ${ }^{84}$.

${ }^{81}$ DC 59. "Para que al orador se le oiga obedientemente, más peso tiene su vida que toda cuanta grandilocuencia posea", Ídem. Ver también el numeral 63, dedicado al mismo tema de la oración previa a la predicación.

${ }^{82} \mathrm{DC} 60$.

${ }^{83}$ DC 61.

${ }^{84}$ La indicación de algunos personajes y de algunos momentos en la historia de la predicación nos permitirá verificar esta afirmación. El apóstol San Pablo solicitaba a los fieles orar por él para que pudiera anunciar la Palabra como era necesario: "Rogad por mí, con el fin de que me sea dado abrir la boca para hablar y anunciar con fuerza el Misterio del Evangelio, del que soy embajador en mis cadenas; obtenedme la valentía de hablar de él como debo hacerlo", Ef 6, 19-20. Durante la época Patrística las formas de predicación se multiplican siguiendo las necesidades pastorales, de las que son reflejo: la formación doctrinal, Cfr. San Juan Crisóstomo, Catéchèses bautismales, Ed. A- Wenger, SC 50, Patris, Cerf, 1957; la lucha contra las herejías, en particular San Agustín. (Cfr: Contra Faustum Manichqeum, XXII, 91: Patrologia cursus completus. Serie latina (PL) 42, 461; San Gregorio el Grande (+604), Règle pastorale t. II, en Sources Chrétiennes 382, Cerf, Paris, especialmente los capítulos 36, p. 519-523; cap. 39, p. 529-531. Homélies sur Ezechiel, en Sources Chrétiennes 327 y 360, ver especialmente homilías XI, 12-17, p. 465, 469; XI, 27-29, p. 487-491). Además del conocimiento profundo que San Gregorio tenía de los hombres y de su tiempo, sus homilías muestran una inteligencia aclarada puesta al servicio de la Predicación a los más humildes. Y si no se habla aquí de san Agustín, es porque se ha tratado al interior del artículo). Para la Edad Media, que baste con recordar algunos ejemplos de esta renovación constante de la predicación eclesial: las Órdenes Mendicantes pronunciaron una palabra exhortativa (predicare penitentiam) que iba al corazón del pueblo gracias al testimonio que la acompañaba. (Cfr. San francisco de Asís, Primera 
En segundo lugar, algunos estudios sobre las dificultades y los problemas a los cuales la homilía se enfrenta hoy dan cuenta de la crisis de la predicación. Estos estudios muestran la incapacidad de gran número de homilías para hacerse entender: parecen insignificantes y aburridas, carecen de interés y de fuerza movilizadora ${ }^{85}$. En tercer lugar, es necesario anotar que la homilía, aunque considerada sólo como una exposición hecha a un auditorio, no está exenta de exigencias y de dificultades que todo discurso conlleva. Está, entonces, sumisa a fenómenos tales como la deformación o los malentendidos del lenguaje, la acústica, la articulación, la incomprensión, la ineficacia, la inadaptación, la monotonía, etc. Dejando de lado los problemas de orden

Regla 21, 3-9; 23, 7; Segunda Regla 9, 3-4, en Écrits, col. Sources Chrétiennes 285, Cerf, Ed. Franciscaines, Paris, 1981). Los Franciscanos y los Hermanos Predicadores (Los Dominicos) se prepararon cada vez mejor para esta tarea. Resulta de ello una predicación sabia realizada por los grandes maestros de estas Órdenes de los que San Buenaventura y Santo Tomás son los más importantes. (Cfr. San Buenaventura, Comm in Eccl., II, 7 (VI 90). No se puede pasar por alto la diversidad de modalidades empleadas en la predicación popular de la Edad Media: los ejemplos (Exempla), la iconografía de las catedrales, los Misterios representados en los atrios de las iglesias, etc., tanto como los medios que utilizaba el orador buscando un objetivo adaptado y práctico: "Predica los diez mandamientos, los artículos de fe, los sacramentos, los últimos fines, reconfortando a los buenos y esforzándote por asustar a los malos", fórmula de un predicador medieval citada por $\mathrm{O}$. de la Brosse, Initiation à la pratique de la théologie, t.1 Pratique, Cerf, Paris, 1987, p. 128. Cfr. J. de Vorágine, Légende dorée, int., trad y notas Teodor de Wyzwa Librairie académique Perrin, Paris, s.d. (1960), $2^{\circ}$ vol. (reed. De la trad. de 1990). Durante la época de la reforma y de la contra reforma conviene recordar a San Francisco de Sales, apóstol y pastor a Ancy. La multitud de imágenes de que se sirve este doctor de la Iglesia muestra un interés pastoral fundamental: poner la vida espiritual al alcance de los laicos. (Cfr. Tratado de la predicación, en Obras completas de san Francisco de Sales, t. II, París, Albanel et Martin, 1839, p. 5-30. Introducción a la vida devota, en Obras completas de San Francisco de Sales, t. 3, ed. J. Neérat, Annecy, 1893; ver especialmente la primera parte, Capítulo III: "Que la devoción es conveniente para toda clase de vocaciones y profesiones", p. 19-21). En fin, y dando un gran salto que pasa por alto a predicadores como Alfonso María de Ligorio, Bossuet, Leonardo de Puerto Mauricio, entre otros, mencionemos al Papa Juan XXIII que habló de la promoción de la doctrina cristiana en la apertura del Concilio Vaticano II y exhortó a todos los participantes a ponerse en el trabajo que exigía nuestra época: presentar la Buena Nueva de la manera que responda mejor a las exigencias actuales. El Papa indica que cumplir esta tarea es "seguir la ruta en la que la Iglesia marcha desde hace más de veinte siglos". (Cfr. Juan XXIII, "Discurso de apertura del Concilio", en Discurso al Concilio, col. Documents Conciliaires 6, Paris, Centurion, 1966, p. 63).

${ }^{85}$ Cfr. Huscenot J, L'homélie en question, Langres, Dominique Gueniot, 1980, p. 81-150; Chautard, G, “l'homélie plaide non-coupable”, en Etudes (Mayo 1985), p. 686-688; Laurent J. P., "Filtrer la Bonne Nouvelle", en Lumen Vitae XXXV (1980) 2, p. 162-185; Marconot J.-M., Comment ils prêchent, Paris, Cerf, 1976, p. 87-197; Traulle C, "Propos et questions sur la prédication”, en La Maison-Dieu, 126 (1976), p. 100ss. LENDGER André, La predicación. Compromiso de hablar bien, Salamanca, Ed. San Esteban, 2011, p. 13-17. 
acústico y retórico, que por tanto no deben descuidarse, se puede afirmar que muchos sermones actuales "no hablan", que resultan insignificantes y que no suscita ningún movimiento de conversión entre los auditores. En cuarto lugar, esto es lo que ha reconocido con valentía la Iglesia latinoamericana: "Por su parte la Iglesia y la catequesis siguen atadas a formas de comunicación que no siempre logran llegar a lo profundo de la vida y de las personas. Hay un sentimiento de impotencia. Teniendo un mensaje de gran calidad y de gran actualidad no saben cómo entregarlo, o lo entregan sin fuerza, o simplemente no lo entregan de ninguna manera. Y así el evangelio queda en desventaja con relación a otros muchos mensajes que se proclaman" $"$.

Es posible entonces afirmar que hay una crisis del lenguaje religioso que se sitúa en el centro mismo de lo que el Papa Pablo VI llamaba, utilizando el vocabulario teatral, un drama: "la ruptura entre Evangelio y cultura es sin duda el drama de nuestra época"87. Dicho de otra manera, la crisis del lenguaje religioso es el signo de una nueva situación: la Iglesia se encuentra confrontada a un contexto social transformado. Por consiguiente, no dirige hoy más la palabra a personas que tengan el estado mental de antes. Cambios sociales muy rápidos tuvieron por consecuencia la aparición de un desfase entre el mundo contemporáneo y la Iglesia, desfase que es descrito con frecuencia como una ruptura entre cada uno de estos dos polos: Iglesia y Sociedad.

En este contexto, la búsqueda de vías y de medios de una predicación más interpelante y más eficaz constituye algo más que un simple problema de adaptación. El hecho de examinar la crisis del lenguaje religioso desde la teología práctica implica la elaboración de una reflexión teológica sobre la Revelación, que va de par con la puesta en práctica de las diferentes soluciones tendientes a afrontar el problema. Cualquiera que sea la interpretación que se dé a la crisis del lenguaje religioso, la investigación de las vías y medios para responder a ello implica inevitablemente un doble movimiento. Por una parte, el que va de la teoría hacia la práctica, en el sentido que la búsqueda

\footnotetext{
${ }^{86}$ CONFERENCIA EPISCOPAL LATINOAMERICANA (CELAM), La catequesis en América Latina. Orientaciones comunes a la luz del Directorio General para la Catequesis, Bogotá, Celam, 1999, $\mathrm{n}^{\circ}$ 131. También se puede leer al respecto esta afirmación del Documento de Aparecida: En la evangelización, en la catequesis y, en general, en la pastoral, persisten también lenguajes poco significativos para la cultura actual, y en particular, para los jóvenes. Muchas veces, los lenguajes utilizados parecieran no tener en cuenta la mutación de los códigos existencialmente relevantes en las sociedades influenciadas por la postmodernidad y marcadas por un amplio pluralismo social y cultural" ( $\left.\mathrm{n}^{\mathrm{o}} 100 \mathrm{~d}\right)$.

${ }^{87} \mathrm{EN} \mathrm{n}^{\circ} 20$.
} 
de una competencia comunicativa que logre colmar la brecha entre la Iglesia y el hombre contemporáneo es inseparable de la reflexión teológica. Por otra parte, un movimiento que va de la práctica hacia la teoría, en el sentido que la puesta en práctica de nuevos métodos de predicación, por el hecho de su confrontación con la realidad concreta, permite descubrir que las nuevas condiciones sociales en las que se realiza la homilía juegan un rol que no es únicamente el de simple condicionamiento nuevo de una doctrina inmutable. Por el contrario, la nueva situación cumple un rol de estructuración de la nueva comprensión de la práctica pastoral y de la misma fe predicada.

\section{Desafíos de la predicación contemporánea}

El recorrido hecho hasta aquí permite ver con una mirada crítica, pero también pro-activa o propositiva, algunos de los fenómenos homiléticos de hoy. Estas últimas líneas se van a plantear articulándolas en torno a tres desafíos fundamentales que tiene la homilética hoy: ¿Cómo superar el doctrinalismo? ¿Cómo superar el emocionalismo? ¿Cómo superar el practicismo?

Se puede notar que estos tres retos están en estrecha relación con los tres objetivos que plantea san Agustín para la predicación cristiana: ilustrar, deleitar y mover. Y hay que subrayar enseguida que el problema es su desarticulación o el desequilibrio que se produce cuando uno de estos aspectos se sobrepone al otro de forma apabullante. En cuanto al primero, hay que afirmar que en realidad brilla más bien por su ausencia. Uno de los grandes teóricos de la predicación contemporánea, F. Craddock, afirma que detrás de cada homilía deberíamos poder extraer una idea teológica fundamental ${ }^{88}$. Pero hacer ese ejercicio, en muchos casos, llevaría a encontrarse con una decepción, porque lo que se puede extraer de muchas homilías actuales son viejas teologías que el Concilio Vaticano II mandó recoger pero que se siguen pregonando en algunos púlpitos. En realidad, muchas de las homilías actuales no ilustran, es decir, no enseñan. Porque no son capaces de presentar el contenido de la fe de forma pertinente a las necesidades e inquietudes de los hombres y mujeres de hoy. Les hace falta teología a las homilías, les hace falta sustancia teológica. ¿Cómo obedecerán si ignoran lo que deben creer y lo que deben hacer? ${ }^{89} \mathrm{Se}$ preguntaba San Agustín, hablando de la necesidad de ilustrar.

${ }^{88}$ CRADDOCK Fred B, Prêcher, Ginebra, Labor et Fides, 1991, p. 48-49. 53-65.

${ }^{89}$ DC 6. 
Y cuando se piensa en la importancia que dio San Agustín al estudio hasta el final de su vida, en especial la doctrina que elaboró para escudriñar las Escrituras y cómo se sirvió de las ciencias de su tiempo, hay lugar para interrogarse: ¿Qué está pasando con la formación teológica de los predicadores? ¿Por qué no logra pasar la formación teológica a la predicación? ¿Por qué no se deja transparentar una re-interpretación de la Sagrada Escritura, de la Tradición, del Magisterio y de la Doctrina Social en las homilías? ¿Por qué ese vacío? Detrás de la labor evangelizadora de san Agustín a través de sus sermones aparece una convicción profunda: ¡Que la fe nunca sea percibida como una renuncia a la inteligencia! Y hoy, como en la época de san Agustín, el predicador debe-antes de hablar-haberse nutrido abundantemente de la actual reflexión teológica, haber profundizado la fe, para derramar oportunamente sobre los auditores lo que ha asimilado. Desafío enorme que implica construir interpretaciones novedosas, como las que hace san Agustín en cada sermón, como la que elaboró ante acontecimientos como el de la caída de la Roma y el final del Imperio. Tarea hermenéutica que muchos fieles anhelan ver cada domingo en las eucaristías.

En cuanto al emocionalismo, el reto es interesante. Los hermanos de las Iglesias cristianas saben inyectarle a los sermones mucha emoción, cierta pasión; incluso y con frecuencia, cierta vehemencia desaforada que pareciera indicar que la presencia del Espíritu dependiera de la pujanza estomacal del predicador. Y lo que se constata, en medio de todas las ambigüedades que implica tal predicación, es que los jóvenes acuden, que la gente se siente feliz, que muchos prefieren esa participación activa y emocionada en los cultos que las misas lánguidas de las Iglesias católicas, en donde hay que hacer un esfuerzo incluso para entender lo que se dice o para protegerse del eco estridente de un micrófono mal regulado. En todo caso, ese emocionalismo corre un grave peligro: reducir la fe a lo que se siente, medir todo en función de un cierto gustillo interior. Esa predicación fogosa puede quizás no llegar al corazón, al hondón del alma, porque toca sensibilidades ciertamente, pero no conmueve las convicciones.

De todas maneras, como lo afirma San Agustín, deleitar no es un defecto. Agradar con la palabra homilética no es un pecado. La forma, inseparable del contenido, juega un papel no solo mediador, sino que es en realidad lo que el agua en el bautismo o el óleo en la confirmación. Como lo diría McLuhan, "el medio es el mensaje". Y muchos predicadores católicos lo han comprendido, porque eso es profundamente católico: no se va directamente a Dios sino por medio de intermediarios, por el hermano, por la Iglesia, por la Palabra, por los sacramentos, por la propia psicología, por la ciencia, etc. 
Aquí habría que decir que a través de las palabras nos llega la Palabra, que a través de la estética discursiva se avizora la belleza divina, que a través de los signos de un discurso bello se presiente la insondable riqueza de la Gracia ${ }^{90}$. Emocionar, deleitar, agradar requiere un largo trabajo que hoy la cultura cibernética no favorece mucho. Porque hablar bien pasa por otros canales que la retórica conoció y cultivó. Agradar sin volverse meloso, reprender, exhortar, emocionar, impresionar, inquietar, he ahí tantas posibilidades que puede desarrollar la palabra homilética.

En cuanto al practicismo, aunque ciertamente la finalidad del sermón ha de ser propiciar cierta "disposición para la acción", se puede temer que los creyentes tengan aquí que elaborar un serio proceso de discernimiento. Dejando por sentado que la fe se expresa en una caridad activa, que la fe sin obras está muerta, que la fe cristiana es ante todo seguimiento efectivo de Jesús, se perciben, sin embargo, unos desequilibrios que, en el contexto utilitarista actual, se podría definir así: tendencia a reducir la fe cristiana a la ética; exaltación excesiva de la acción en detrimento de la pausa, del recogimiento y de la gratuidad de la oración. Por un activismo que no brota de la fe sino del afán de autoafirmación, se deja de lado la escucha, el silencio, la mística contemplativa que se cultiva ciertamente en la acción, pero que requiere de espacios de silencio gratuito, de inactividad acogedora de la Gracia transformante ${ }^{91}$.

A lo largo de todas estas reflexiones se ha insistido en la importancia de la retórica, de la calidad del discurso; se ha subrayado la preocupación de bien comunicar, la inteligibilidad de la palabra predicada, la adaptación a los diferentes públicos; en resumen, se ha formulado la necesidad de su "eficacia". Pero sería inexacto, por decir lo menos, no señalar los límites de todo esto. En efecto, según san Agustín, la actividad del predicador se sitúa al exterior, del lado del Verbo hecho carne, pero está completamente al servicio del encuentro de cada auditor con el Verbo interior. Lo que dice el predicador, por

\footnotetext{
90 "Y sin embargo, Dios, aunque de El no podemos decir cosa alguna, escucha la ofrenda de nuestra voz, y quiere nos alegremos con nuestras voces dirigidas en alabanza de Él. De aquí procede que se le llame Dios. Ciertamente que no se le conoce por el ruido de estas dos sílabas De-us, pero los conocedores de la lengua latina, al percibir sus oídos este sonido, los excita a pensar en una naturaleza excelentísima e inmortal”, DC, I, 6, 6.

${ }^{91}$ Para una profundización sobre la necesidad de recuperar el silencio y evitar el frenesí de la vida actual ver los siguientes textos: DEISON S. Il canto del silenzio. Alla scoperta di una dimensione perduta. Paoline: Milano, 1995; HUSILLOS TAMARIT I. (ed.). El silencio. II seminario Desierto de las Palmas. Burgos: Ed. Monte Carmelo, 2007; AUGIERI C. A. (ed.). La retorica del silenzio. Atti del Congegno internazionale, Lecce 24-27 ottobre 1991. Lecce: ed. Milella, 1994; BALDINI M. Le dimensioni del silenzio. Roma: Città Nuova Editrice. 1988.
} 
muy ilustrativo, bello o conmovedor que sea, es siempre una admonitio, una advertencia, un llamado a la memoria. Por causa del pecado esta advertencia es necesaria, porque "nadie busca a Dios sin haber sido amonestado" ${ }^{92}$. Pero esta admonición, aunque necesaria, es insuficiente.

Por esto, sin desconocer el papel de predicador, hay que señalar que es relativo, porque para Agustín lo esencial es que el predicador remita al Verbo interior. Y de aquí saca Agustín una lección de humildad y pone en el puesto que corresponde al predicador ${ }^{93}$. Es Dios quien da crecimiento a lo predicado, es Dios quien trabaja los corazones, la voluntad y la inteligencia de los auditores. La oratoria es un medio humano que no basta. Por eso hay que orar y dar ejemplo. Porque orar es una forma de mostrar a los auditores que el predicador está en la misma escuela que los oyentes de sus sermones ${ }^{94}$; por eso testimoniar es mostrar que el predicador es el primero en haber obedecido a Dios que predica. De ahí que si no se debe descuidar ninguna técnica oratoria, no se debe tampoco creer que ellas basten por sí mismas para hacer escuchar al Maestro interior.

Por eso, para terminar, conviene dejar hablar una vez más al mismo San Agustín: "El sonido de nuestras palabras golpea sus oídos, el Maestro está en el interior. No crean que se aprende algo de otro hombre. Nosotros podemos atraer su atención con el ruido de nuestra voz: si al interior no está el que instruye, vano es el ruido de nuestras palabras... las enseñanzas exteriores son una ayuda, una invitación a atender. Es en el cielo donde está la cátedra del que instruye los corazones... Es pues el Maestro interior quien instruye, es Cristo quien instruye ${ }^{95}$... Por eso el predicador solo puede invitar a cada uno a dilatar su corazón: "avanza en aguas profundas! ¡Despiértate!”96.

92 Soliloquios, I, 1, 3. El hijo de Agustín, Adeodato, lo expresa así: "Pero yo, aprendí por la advertencia (admonitione) de tus palabras que las palabras sólo advierten (admoneri) al hombre para aprender, y que hay pocas posibilidades de que el lenguaje revele algo del pensamiento del que habla; pero la verdad de lo que se die, solo nos la enseña (docere) aquel que, cuando habla exteriormente (foris), nos advierte que él habita en el interior (intus), De Magistro, 14, 46. ${ }^{93}$ Ver por ejemplo lo que dice en De Catechizandis rudibus, 7,11 , en donde señala que el que es tocado por la predicación y comienza a cambiar de vida, que no le atribuya eso ni al predicador ni a sí mismo, sino a Dios, que lo amó antes de ser amado, para hacerlo su propio amigo.

94 "Nosotros ocupamos un lugar más elevado por la predicación, pero somos discípulos en la misma escuela, y todos tenemos un mismo maestro en los cielos", Sermon 298, 5.

${ }^{95}$ In Jo. Ep. 3, 13.

${ }^{96}$ Ibíd., X, 6-7. La distinción entre el predicador como voz y Cristo como Palabra, se encuentra en el sermón 288, 3-4. En fin de cuenta la palabra es lo que cuenta, pero la palabra ha querido valerse de la voz para comunicarse. 


\section{Referencias Bibliográficas}

AGUSTÍN Obras de San Agustín, tomo 15, De Doctrina christiana. Madrid: BAC, 1957.

AGUSTÍN. Obras de San Agustín, tomo 1, Soliloquios... Madrid: BAC, 1969.

AGUSTÍN. Obras de San Agustín, tomo 10, Sermones, 51-116. Madrid: BAC, 1983.

AGUSTín. Obras de San Agustín, tomo 23, Sermones, 177-183. Madrid: BAC, 1983.

AGUSTÍN. Obras de San Agustín, tomo 13, Tratados sobre el evangelio de san Juan 1-35. Madrid: BAC, 1955.

AGUSTÍN. Obras de San Agustín, tomo 14, Sermones 184-273B. Madrid: BAC, 1983.

AGUSTÍN. Obras de San Agustín, tomo 24, Tratados sobre el evangelio de san Juan 36-124. Madrid: BAC.

AGUSTín. Obras de San Agustín, tomo 16, Sermones 339-396. Madrid: BAC, 1985.

AGUSTín. Obras de San Agustín, tomo 2, Confesiones. Madrid: BAC, 1979.

AGUSTÍN. Obras de San Agustín, tomo 25, Sermones 273-338. Madrid: BAC, 1984.

AGUSTÍN. Obras de San Agustín, tomo 3, De Magistro. Madrid: BAC, 1963.

AGUSTÍN. Obras de San Agustín, tomo 39, De Catechizandis rudibus. Madrid: BAC, 1988.

ALBERICH, Emilio. - DERROITTE, Henri. - VALLABABARAJ, Jérôme. Les fondamentaux de la catéchèse. Bruselas- Quebec: Ed. Lumen Vitae - Novalis, 2006.

AQUIEN Michèle - MOLINIÉ Georges. Dictionnaire de rhétorique et de poétique, París, Le Livre de Poche, 1996, p. 7-25.

CHAUTARD, G. "L'homélie plaide non-coupable", en Etudes (Mayo 1985), p. 686-688. 
CONFERENCIA EPISCOPAL LATINOAMERICANA (CELAM). La catequesis en América Latina. Orientaciones comunes a la luz del Directorio General para la Catequesis Bogotá: CELAM, 1999.

CRADDOCK Fred B. Prêcher. Ginebra: Labor et Fides, 1991.

DE LA BROSSE O. Initiation à la pratique de la théologie, t.1 Pratique, París: Cerf, 1987.

DE VORAGINE Jacques. Légende dorée. París: Librairie académique Perrin, 1960.

DENEKEN Michel- PARMENTIER Elisabeth. Pour quoi prêcher. Plaidoyer catholique et protestant pour la prédication, Ginebra: Labor et Fides, 2010.

FOSSIÓN André. Dieu désirable. Proposition de la foi e initiation. Bruselas: Ed. Lumen Vitae, 2010.

FRANCISCO DE SALES. Introducción a la vida devota, en Obras completas de San Francisco de Sales, t. 3. Annecy: ed. J. Neérat, 1893.

FRANCISCO DE SALES. Tratado de la predicación, en Obras completas de san Francisco de Sales, t. II. París: Albanel et Martin, 1839.

HUSCENOT Jean. L'homélie en question. Langres: Dominique Gueniot, 1980.

LAUSBERG H. Manual de retórica literaria. Fundamentos de una ciencia de la literatura. Tomo I. Madrid: Gredos, 1966.

JUAN CRISÓSTOMO. Catéchèses bautismales. París: CERF, SC 50, Patris, 1957.

KAEMPS Bernard (Dir.). Introduction à la théologie pratique. Estrasburgo: Presses Universitaires de Strasbourg, 1997.

LAURENT J. P. Filtrer la Bonne Nouvelle. Lumen Vitae XXXV (1980) 2, pp. 162-185.

LENDGER André. La predicación. Compromiso de hablar bien. Salamanca: Ed. San Estéban, 2011.

MARCONOT Jean-Marie. Comment ils prêchent. Paris: Cerf, 1976. 
PONTIFICIA COMISIÓN BÍBLICA. La interpretación de la Biblia en la Iglesia, Madrid, PPC, 1994.

SERTILLANGES D. El orador cristiano, Madrid - Buenos Aires, Ediciones Studium, 1954.

SICILIANI José María. Contar la Buena Nueva. Bogotá: Ed. Antropos, 2012. VIAU Marcel. "De la théologie pastorale à la théologie pratique", In: Gilles Routhier - Marcel Viau (Dir.), Précis de théologie pratique, París - Bruselas - Montreal: ediciones L'Atélier - Lumen Vitae - Novalis, 2007², pp. 41-53.

José María Siciliani Barraza

Doctor en Teología

Doctor en Filosofía

Profesor en la Universidad de La Salle Bogotá

Bogotá/Cundinamarca - Colombia

E-mail: josemariasiciliani@gmail.com

Recebido em: 24/04/14

Aprovado em: 30/06/14 